\title{
Water and Temperature Parameters Associated with Winter Wheat Diseases Caused by Soilborne Pathogens
}

\author{
Richard W. Smiley, Professor, Oregon State University, Columbia Basin Agricultural Research Center, Pendleton \\ 97801
}

\begin{abstract}
Smiley, R. W. 2009. Water and temperature parameters associated with winter wheat diseases caused by soilborne pathogens. Plant Dis. 93:73-80.

Wheat in eastern Oregon is produced mostly as a 2-year rotation of winter wheat and summer fallow. Maximum agronomic yield potential is expected with early September planting dates but actual yields are generally highest for plantings made in mid-October. Field experiments with sequential planting dates from early September to December were performed over 4 years. Associations among yield, disease incidence, and 19 moisture and temperature parameters were evaluated. Incidence of Cephalosporium stripe, crown rot, eyespot, and take-all decreased as planting was delayed. Crown rot and eyespot were negatively correlated more significantly and more frequently with temperature than moisture parameters, and take-all was more associated with moisture than temperature. Rhizoctonia root rot was unrelated to planting date and climatic parameters. Crown rot was identified most frequently (4 of 5 tests) as an important contributor to yield suppression but yield was most closely associated $\left(R^{2}>0.96\right)$ with effects from a single disease in only two of five location-year tests. Yield was most related to combinations of diseases in three of five tests, complicating development of disease modules for wheat growthsimulation models.
\end{abstract}

Additional keywords: Cephalosporium gramineum, Fusarium pseudograminearum, Helgardia herpotrichoides, Pseudocercosporella herpotrichoides, Rhizoctonia solani AG-8, Triticum aestivum

The timing of winter wheat (Triticum aestivum L.) planting in semiarid eastern Oregon and Washington often has a dramatic effect on incidence and severity of root, crown, and culm diseases caused by soilborne plant-pathogenic fungi (27). Early planting (late August to late September) is generally associated with greatest damage from Cephalosporium stripe, Fusarium crown rot, eyespot, Rhizoctonia root rot, and take-all. Planting in late autumn enhances the incidence of Pythium damping-off. However, the specific relationship between planting date effects on these diseases and environmental parameters remains unclear, particularly in view of variations perceived to occur over crop years. An improved understanding of climatic effects is needed to improve the accuracy of predictions of disease occurrence and implementation of management options. For instance, the MoreCrop expert system (23) for predicting wheat disease incidence and severity in the Pacific Northwest (PNW) is based on broad generalizations of seasonal climatic data. Cur-

Corresponding author: R. Smiley

E-mail: richard.smiley@ oregonstate.edu

Accepted for publication 24 September 2008.

doi:10.1094/PDIS-93-1-0073

(C) 2009 The American Phytopathological Society rent knowledge of associations between root, crown, and culm diseases with soil temperature and moisture are also inadequate for use in disease management modules in the MODCROP and MODWht3 models of wheat growth and morphology in the PNW $(32,43)$.

Most wheat in the PNW is produced with 250 to $400 \mathrm{~mm}$ of annual precipitation, with little or no effective rain occurring during the warm to hot summer months from June to August (37). The most profitable dryland cropping system in the region is a 2-year rotation of winter wheat (10-month growing period, October to July) and summer fallow (14 months, August to September) (36). The onset of autumn rainfall events capable of wetting the upper soil profile for seed germination and seedling establishment are highly variable in the region, occurring as early as mid-September or as late as November, at which time the mean soil temperature in the root zone can approach freezing (41). Optimal soil temperature for seed germination and coleoptile elongation are about 25 and $16^{\circ} \mathrm{C}$, respectively. Both stages are favored by soil water potential near field capacity, with the lower threshold for good emergence, about $-1.5 \mathrm{MPa}$, increasing with increasing temperature (28). Optimal winter wheat yields typically occur when wheat is planted during early October (8), which is often much earlier than allowed by recurring autumn rain events. There- fore, optimal planting dates in the PNW are very different than those in the northcentral United States, where yield of winter wheat is highest for planting dates in late August and early September (16). Wheat production in the north-central region is favored by factors that are uncommon in the PNW; summer rainfall, rotation of wheat with broadleaf crops, shallow planting depth, and comparatively greater prevalence of foliar than root, crown, and culm diseases.

To meet the environmental challenges in the PNW, a highly integrated system of summer fallow management coupled with the use of "deep-furrow" seed drills is used to enable growers to plant fallowed fields during the time interval for maximum theoretical agronomic yield potential (37). This system enables wheat seed to be planted very deep without greatly hindering stand establishment. A moistureconserving "dust-mulch" summer fallow system is used to store water from the winter of the "summer-fallow crop year", which occurs about 6 months before fields are planted. Moisture is preserved in the fallow by cultivating multiple times during the summer with a rod weeder consisting of a rotating $2.5-\mathrm{cm}$ square bar drawn horizontally through soil to compact the soil below the bar and fluff the soil above the bar, creating an air-dry dust mulch that effectively retards capillary water movement upward from moist soil lying 8 to 20 $\mathrm{cm}$ below the soil surface. The rod weeder also controls weeds that may emerge following periodic light rainfall events during summer. This system for "early" planting, from late August to mid-September, promotes high rates of tillering, mostly 5 to 6 tillers and occasionally up to 12 tillers/plant, and reduces competition from winter annual grass weeds that depend upon initiation of rain events for seed germination. Early planting is also used to establish plant stands with sufficient stored carbohydrates in crown tissue to withstand damage when soils freeze during winter. Deep-furrow drills are designed to plant seed deeply ( 8 to $18 \mathrm{~cm}$ ) into moist, warm soil, and are typically set at wide row spacing $(36$ to $41 \mathrm{~cm}$ ) and low seeding rate. The soil surface above the seed row is depressed to allow seedling emergence sooner than would occur with a uniform surface topography. As late summer transitions into early autumn during years with little or no rainfall during that period, the 
soil water content adequate for seed germination and seedling emergence (approximately $12 \%$ or $-0.2 \mathrm{MPa}$ ) recedes deeper into the soil profile at the same time that soil temperature is rapidly declining. Plantings made from mid-September to mid-October are often made at progressively deeper depths to "follow the moisture." Ultimately, the moisture becomes too deep and soil temperature too cold for adequate emergence from deeply planted wheat seed. Growers must decide when to switch to a style of drill that plants wheat seed at a shallow depth into recently moistened soil, or into dry soil when rain events are anticipated. Wheat planted from late October to early December is generally planted shallowly with narrow row spacing and comparatively higher seeding rate because late-planted wheat generally has as few as two or three tillers per plant.

The objectives of this research were to quantify the effect of sequential planting dates using appropriate drills and agronomic practices on incidence and severity of diseases on roots, crowns, and lower culms of the dominant cultivar of winter wheat produced in eastern Oregon, and to evaluate associations among measures of diseases and yields with moisture and temperature parameters. A third objective was to determine whether the expected decline in incidence of crown rot over sequential planting dates occurred when the type of grain drill used was held constant but planting depth varied over sequential planting dates.

\section{MATERIALS AND METHODS}

Experiment 1. The study was performed from 1995 to 1999 at Oregon State University's Columbia Basin Agricultural Research Center near Pendleton, OR. The soil was a deep $(>1.5 \mathrm{~m})$ Walla Walla silt loam; coarse-silty, mixed, superactive, mesic Typic Haploxerolls. Different fields were used each year due to the winter wheat-summer fallow rotation.

Winter wheat cv. Stephens was planted on four dates during crop year 1996 and on five dates during crop years 1997, 1998, and 1999. During the first two plantings each year, from early to mid-September (Tables 1-3), wheat was planted using a John Deere HZ split-packer deep-furrow drill with hoe-type openers at $36-\mathrm{cm}$ row spacing. Seed was planted at a rate of 194 $\mathrm{seed} / \mathrm{m}^{2}$ and a depth of 8 to $10 \mathrm{~cm}$, resulting in seed placement $2 \mathrm{~cm}$ into moist soil with an overburden of air-dry soil up to 4 $\mathrm{cm}$ deep at the bottom of a surface furrow. Subsequent plantings were made using a seeding rate of $280 \mathrm{seed} / \mathrm{m}^{2}$ and a Hege 55 plot drill that placed seed at a $1-$ to $6-\mathrm{cm}$ depth, depending on soil moisture and temperature for each planting date. The drill was equipped with 'Gaines' hoe-type openers at $30-\mathrm{cm}$ row spacing for the third planting and with double-disc openers at $15-\mathrm{cm}$ row spacing for the fourth and fifth plantings. Average depth of seed placement and gravimetric soil water content at seed depth were measured for each planting date. Approximate relationships between soil matric potential (MPa) and gravimetric water content (wt/wt) in this soil $(31)$ are $-2.5 \mathrm{MPa} \approx 7 \%,-0.4 \mathrm{MPa} \approx$ $10 \%,-0.16 \mathrm{MPa} \approx 12 \%$, and $-0.08 \mathrm{MPa} \approx$ $15 \%$.

Each 3-by-9-m plot was replicated four times in each nonreplicated, sequentially positioned planting-date block. Wheat seed was commercially treated with carboxin, thiram, and lindane (Vitavax-ThiramLindane; Gustafson LLC, Plano, TX) at application rates used for commercial crops. Fertilizers were applied uniformly across each plot using a shank applicator before the first planting date. Fertilizers were applied as solutions of anhydrous ammonia and ammonium polysulfide at rates of $\mathrm{N}$ at $112 \mathrm{~kg} / \mathrm{ha}$ and $\mathrm{S}$ at $11.2 \mathrm{~kg} / \mathrm{ha}$. Granular fertilizer (16-20-0-15 $\left[\mathrm{N}-\mathrm{P}_{2} \mathrm{O}_{5^{-}}\right.$ $\mathrm{K}_{2} \mathrm{O}-\mathrm{S}$ ] at $45 \mathrm{~kg} / \mathrm{ha}$ ) was also broadcast applied and incorporated into the top 10 $\mathrm{cm}$ of soil.

Plants with intact root systems were dug from three randomly selected positions in each plot during late March to early April (e.g., Feekes growth stage 5 to 6). Roots were rinsed to remove adhering soil and 15 plants from each plot were evaluated visually for incidence or severity of diseases expressing symptoms on roots, crowns, and culm bases. Diseases detected were eyespot (Helgardia herpotrichoides (Fron) Crous \& W. Gams = Pseudocercosporella herpotrichoides (Fron) Deighton), crown rot (Fusarium pseudograminearum O'Donnell \& T. Aoki $=F$. graminearum Schwabe group I), Rhizoctonia root rot (Rhizoctonia solani Kühn AG-8), and take-all (Gaeu-

Table 1. Planting date, planting depth, seed-zone moisture and temperature, grain yield, and disease incidence and/or severity for winter wheat cv. Stephens planted on sequential dates during crop years 1996 to 1999 at Pendleton, OR

\begin{tabular}{|c|c|c|c|c|c|c|c|c|c|c|c|c|}
\hline \multirow[b]{2}{*}{ Planting date } & \multirow{2}{*}{$\begin{array}{c}\text { Planting } \\
\text { depth } \\
\text { (cm) }\end{array}$} & \multirow{2}{*}{$\begin{array}{c}\text { Moisture } \\
(\%)^{\mathrm{y}}\end{array}$} & \multirow[b]{2}{*}{$\begin{array}{l}\text { Temp. } \\
\left({ }^{\circ} \mathbf{C}\right)^{z}\end{array}$} & \multirow{2}{*}{$\begin{array}{c}\text { Grain } \\
\text { yield } \\
\text { (kg/ha) }\end{array}$} & \multirow{2}{*}{$\begin{array}{c}\begin{array}{c}\text { Cephalo- } \\
\text { sporium } \\
\text { stripe }\end{array} \\
\begin{array}{c}\text { Incid. } \\
(\% \text { plants })\end{array}\end{array}$} & \multicolumn{2}{|c|}{ Fusarium crown rot } & \multirow{2}{*}{$\frac{\text { Eyespot }}{\text { Incid. }}$} & \multicolumn{2}{|c|}{ Rhizoctonia root rot } & \multicolumn{2}{|c|}{ Take-all } \\
\hline & & & & & & $\begin{array}{c}\text { Incid. } \\
\text { (\% plants) }\end{array}$ & $\begin{array}{c}\text { Severity } \\
(0-4)\end{array}$ & & $\begin{array}{c}\text { Incid. } \\
\text { (\% plants })\end{array}$ & $\begin{array}{c}\text { Severity } \\
(0-4)\end{array}$ & $\begin{array}{c}\text { Incid. } \\
\text { (\% plants) }\end{array}$ & $\begin{array}{c}\text { Severity } \\
(0-5)\end{array}$ \\
\hline \multicolumn{13}{|l|}{ Crop year 1996} \\
\hline 8 Sep 1995 & 11 & 13 & 15 & 2,899 & 0 & 57 & 2.4 & 51 & 69 & 2.2 & 17 & 4.1 \\
\hline 21 Sep 1995 & 8 & 16 & 18 & 5,057 & 0 & 62 & 2.6 & 21 & 78 & 2.8 & 17 & 3.7 \\
\hline 11 Oct 1995 & 3 & 17 & 11 & 5,799 & 0 & 0 & 0 & 0 & 54 & 3.1 & 0 & 0 \\
\hline 30 Oct 1995 & 3 & 17 & 3 & 6,271 & 0 & 0 & 0 & 0 & 36 & 2.6 & 0 & 0 \\
\hline \multicolumn{13}{|l|}{ Crop year 1997} \\
\hline 3 Sep 1996 & 10 & 12 & 21 & 2,966 & 23 & 36 & 1.1 & 7 & 19 & 1.7 & 0 & 0 \\
\hline 20 Sep 1996 & 3 & 10 & 13 & 3,284 & 14 & 27 & 1.4 & 34 & 35 & 2.2 & 0 & 0 \\
\hline 10 Oct 1996 & 6 & 11 & 16 & 5,114 & 5 & 27 & 1.6 & 14 & 37 & 1.9 & 7 & 1.1 \\
\hline 1 Nov 1996 & 2 & 17 & 5 & 4,463 & 8 & 0 & 0 & 8 & 41 & 3.5 & 11 & 1.5 \\
\hline 2 Dec 1996 & 1 & 21 & 2 & 4,838 & 0 & 0 & 0 & 0 & 27 & 2.4 & 6 & 1.3 \\
\hline \multicolumn{13}{|l|}{ Crop year 1998} \\
\hline 5 Sep 1997 & 12 & 12 & 23 & 4,152 & 0 & 59 & 2.2 & 28 & 47 & 2.3 & 28 & 2.6 \\
\hline 19 Sep 1997 & 8 & 13 & 13 & 3,644 & 0 & 64 & 2.5 & 23 & 54 & 2.7 & 34 & 2.9 \\
\hline 10 Oct 1997 & 6 & 15 & 10 & 5,848 & 0 & 11 & 2.4 & 5 & 46 & 2.8 & 19 & 2.7 \\
\hline 28 Oct 1997 & 6 & 14 & 9 & 5,835 & 0 & 5 & 1.8 & 5 & 37 & 3.3 & 23 & 3.7 \\
\hline 21 Nov 1997 & 2 & 17 & 6 & 5,793 & 0 & 0 & 0 & 0 & 32 & 3.1 & 12 & 4.3 \\
\hline \multicolumn{13}{|l|}{ Crop year 1999} \\
\hline 8 Sep 1998 & 14 & 10 & 26 & 4,701 & 0 & 65 & 1.9 & 11 & 21 & 0.7 & 100 & 4.8 \\
\hline 22 Sep 1998 & 10 & 11 & 20 & 4,504 & 0 & 73 & 2.2 & 23 & 47 & 1.0 & 100 & 4.2 \\
\hline 5 Oct 1998 & 5 & 10 & 16 & 5,402 & 0 & 7 & 2.0 & 13 & 57 & 1.1 & 93 & 4.6 \\
\hline 20 Oct 1998 & 2 & 14 & 14 & 4,511 & 0 & 7 & 2.2 & 10 & 87 & 1.6 & 80 & 4.6 \\
\hline 19 Nov 1998 & 2 & 19 & 9 & 3,960 & 0 & 7 & 3.3 & 0 & 39 & 1.2 & 79 & 4.7 \\
\hline
\end{tabular}

y Seed-zone moisture $(\% \mathrm{wt} / \mathrm{wt})$.

z Soil temperature at $10 \mathrm{~cm}$. 
mannomyces graminis (Sacc.) Arx \& D.L. Olivier var. tritici J. Walker).

Eyespot incidence was quantified as the percentage of stem bases with characteristic lesions in the leaf sheath above the soil surface (3). Crown rot incidence was quantified as percentage of plants with subcrown internodes affected by characteristic dark lesions and also as percentage of plants with a brown dry rot of tissue inside the crown. Severity of crown rot was assigned as follows: $0=$ no lesion on the subcrown internode, $1=1$ to $25 \%$ of area affected by lesions, $2=26$ to $50 \%$ lesion area, $3=51$ to $75 \%$ lesion area, and $4=$ $>75 \%$ lesion area. Rhizoctonia root rot incidence was evaluated as percentage of plants on which the main coronal root axes exhibited a brown cortical rot or the "spear tip" severance symptom. Rhizoctonia root rot severity was assessed by a 0-to- 4 scale indicating relative severity of root rot symptoms on crown roots where $0=$ none and $4=$ extensive root rot on most or all roots. The incidence of "dryland" take-all, for which necrosis does not advance upward into the stem and for which stunting of plants and reduced grain yield are seldom severe, was rated as the percentage of plants on which seminal roots exhibited a characteristic blackening of the root cortex or vascular system. Take-all severity was rated on seminal roots using a 0 -to- 5 scale where $0=$ none and $5=$ extensive blackening on most or all roots.

Plots were monitored for other diseases during heading and anthesis. Cephalosporium stripe (Cephalosporium gramineum Y. Nisik. \& Ikata = Hymenula cerealis Ellis \& Everh.) was the only disease expressing symptoms in the foliage and was recorded as percentages of plants exhibiting characteristic yellow leaf stripes emanating from brown vascular bundles in leaf sheaths (3).

Atmospheric weather conditions and soil temperature at $10-\mathrm{cm}$ depth were measured at a U.S. National Weather Service meteorological station located within
$0.5 \mathrm{~km}$ of plots. Weather parameters included cumulative precipitation and growing degree days $\left(0^{\circ} \mathrm{C}\right.$ base) (i) between June 1 (beginning of summer period for summer fallow) and each planting date, (ii) between September 1 (beginning of the winter wheat crop year) and each planting date, (iii) from each planting date to December 31 (midwinter), (iv) for the entire crop year, (v) for a period 21 days before each planting date, and (vi) for a period 21 days after each planting date. Additional parameters included maximum, minimum, and mean daily soil temperatures at a $10-\mathrm{cm}$ depth for each planting date, and soil temperature averaged for 21 days after planting.

Grain was harvested using a Hege 140 small-plot combine. Harvest in each planting-date block occurred from mid-July to early August after grain had dried to less than $12 \%$ moisture.

Disease and yield parameters for planting dates within crop years could not be analyzed by analysis of variance (ANOVA) because planting date blocks were not replicated. Therefore, data were grouped over the 4 years and evaluated by ANOVA using a one-way randomized complete block model (Co-Stat Statistical Software version 6.303; CoHort Software, Mon- terey, CA) with year as treatment and groups of planting dates (first or last half of each month) as blocks. Numbers of planting date intervals were minimized by assigning the single 1 November date into the 16 to 30 October block, and the single 2 December date into the 16 to 30 November block. For the grouped data, take-all was the only variable significantly affected by the treatment effect for year. Cephalosporium stripe occurred during only 1 year and was not evaluated. Because most yield and disease variables were not affected by a treatment effect for year, data were also evaluated by ANOVA using planting date intervals as treatments and years as blocks. When treatment effects were significant at $P<0.05$, means were separated using the least significant difference test (LSD). Regression analyses were performed to identify possible associations between yield, disease, and moisture and temperature parameters within years and for data grouped over 4 years. Stepwise backward multiple regression analysis was also performed to examine combined effects of diseases on yield and of climatic parameters on diseases.

Experiment 2. Winter wheat cv. Stephens was planted on four dates from

Table 3. Mean grain yield and disease incidence for five planting intervals over 4 years (1996 to 1999) at Pendleton, OR

\begin{tabular}{lccccc}
\hline & & \multicolumn{4}{c}{ Plants $(\%)^{\mathbf{y}}$} \\
\cline { 3 - 6 } $\begin{array}{l}\text { Planting } \\
\text { interval }\end{array}$ & $\begin{array}{c}\text { Grain yield } \\
(\mathbf{k g} / \mathbf{h a})\end{array}$ & $\begin{array}{c}\text { Fusarium } \\
\text { crown rot }\end{array}$ & Eyespot & $\begin{array}{c}\text { Rhizoctonia } \\
\text { root rot }\end{array}$ & Take-all \\
\hline 1-15 September & $3,680 \mathrm{~b}$ & $54.3 \mathrm{a}$ & $24.3 \mathrm{a}$ & 42.6 & 36.3 \\
16-30 September & $4,122 \mathrm{~b}$ & $56.5 \mathrm{a}$ & $25.3 \mathrm{a}$ & 60.2 & 37.8 \\
1-15 October & $5,541 \mathrm{a}$ & $11.3 \mathrm{~b}$ & $8.0 \mathrm{ab}$ & 45.7 & 29.8 \\
16-30 October & $5,270 \mathrm{a}$ & $3.0 \mathrm{~b}$ & $5.8 \mathrm{~b}$ & 38.0 & 28.5 \\
16-30 November & $4,700 \mathrm{ab}$ & $2.3 \mathrm{~b}$ & $0 \mathrm{~b}$ & 32.7 & 32.3 \\
Prob. $>F$ & 0.02 & $<0.01$ & 0.05 & 0.28 & 0.18 \\
CV $(\%)$ & 16 & 46 & 87 & 34 & 23 \\
\hline
\end{tabular}

y Values within a column followed by the same letter are not significantly different according to a protected least significant difference test at $P=0.05$.

${ }^{z}$ Analysis of variance was performed with years as replicates. Planting dates of 1 November 1996 and 2 December 1996 were grouped with the nearest earlier half-month planting interval to facilitate analysis with minimal intervals. $\mathrm{CV}=$ coefficient of variation.

Table 2. Incidence of diseases and grain yield for winter wheat cv. Stephens planted on sequential dates during the 1996 crop year at Moro and Pendleton, OR

\begin{tabular}{|c|c|c|c|c|c|c|c|c|c|}
\hline \multirow{2}{*}{$\begin{array}{l}\text { Location and } \\
\text { planting date }\end{array}$} & \multirow{2}{*}{$\begin{array}{c}\text { Planting } \\
\text { depth } \\
\text { (cm) }\end{array}$} & \multirow{2}{*}{$\begin{array}{c}\text { Moisture } \\
(\%)^{\mathrm{v}}\end{array}$} & \multirow{2}{*}{$\begin{array}{l}\text { Temp. } \\
\left({ }^{\circ} \mathbf{C}\right)^{w}\end{array}$} & \multirow{2}{*}{$\begin{array}{c}\text { Grain yield } \\
\text { (kg/ha) }\end{array}$} & \multicolumn{2}{|c|}{ Fusarium crown rot } & \multirow{2}{*}{$\frac{\text { Eyespot }}{\text { (\% stems) }}$} & \multirow{2}{*}{$\begin{array}{c}\text { Rhizoctonia } \\
\text { root rot }\end{array}$} & \multirow{2}{*}{$\frac{\text { Take-all }}{(\% \text { plants })}$} \\
\hline & & & & & $(\% \text { SCI })^{x}$ & $(\% \mathrm{IC})^{\mathrm{y}}$ & & & \\
\hline \multicolumn{10}{|l|}{ Moro $^{z}$} \\
\hline 20 Sep 1995 & 8 & 11 & 14 & 4,538 & 51 & 11 & 0 & 58 & 28 \\
\hline 13 Oct 1995 & 5 & 13 & 10 & 4,774 & 2 & 0 & 0 & 28 & 21 \\
\hline 31 Oct 1995 & 5 & 13 & 5 & 4,167 & 0 & 0 & 0 & 43 & 8 \\
\hline \multicolumn{10}{|l|}{ Pendleton } \\
\hline 8 Sep 1995 & 10 & 14 & 16 & 2,913 & 56 & 12 & 52 & 74 & 28 \\
\hline 21 Sep 1995 & 8 & 16 & 18 & 5,051 & 62 & 11 & 32 & 95 & 15 \\
\hline 11 Oct 1995 & 4 & 17 & 10 & 5,765 & 0 & 0 & 0 & 78 & 0 \\
\hline 31 Oct 1995 & 3 & 17 & 4 & 6,257 & 0 & 0 & 0 & 52 & 0 \\
\hline
\end{tabular}

${ }^{\mathrm{v}}$ Seed-zone moisture $(\% \mathrm{wt} / \mathrm{wt})$.

${ }^{\mathrm{w}}$ Soil temperature at $10 \mathrm{~cm}$.

${ }^{x}$ Percentages of plants with visible lesions on the subcrown internode (SCI).

${ }^{y}$ Percentages of plants with infected crowns (IC) showing brown discoloration.

${ }^{\mathrm{z}}$ Wheat planted at Moro on 6 September 1995 failed to establish an acceptable plant stand due to soil crusting caused by rain 1 day after planting. 
early September to late October 1995 at two additional locations during crop year 1996. Locations were the Columbia Basin Agricultural Research Stations near Moro and Pendleton, OR. Soil texture and classification are the same at Moro and Pendleton but mean annual precipitation is 282 and $442 \mathrm{~mm}$, respectively. All plantings were performed with the John Deere HZ deep-furrow drill described earlier, using the same seeding rate. Planting depth varied by location and date, with the objective of placing seed as shallowly as possible into soil moist enough for rapid seed germination and seedling emergence. Plots were 1.5 by $12 \mathrm{~m}$ and replicated five times in each nonreplicated planting-date block. Sampling to assess diseases and yield was performed as described for experiment 1.

\section{RESULTS}

Precipitation. Precipitation at Pendleton was highest for crop years 1997 (550 $\mathrm{mm}$ ), lowest during crop year 1998 (395 $\mathrm{mm})$, and intermediate during crop years $1996(482 \mathrm{~mm})$ and 1999 (466 mm). Precipitation from June 1 to the first planting date in September was higher during crop years $1996(75 \mathrm{~mm})$ and $1998(43 \mathrm{~mm})$ than crop years 1997 (none) and 1999 (29 $\mathrm{mm}$ ). During crop year 1996, rainfall after the first planting occurred at an abovenormal rate through all subsequent planting dates. Soil surface crusting caused by rainfall before seedling emergence led to stand failure for the first planting date at Moro. During crop year 1997, the first three plantings were made under abnormally dry conditions, and rainfall was abundant before the last two plantings. Seed-zone moisture was adequate for rapid germination during all planting dates in crop years 1996 and 1998 but was marginal $(<12 \%,>-0.2 \mathrm{MPa})$ for germination and emergence during one or more planting dates during crop years 1997 and 1999 (Table 1).

Temperature. Accumulation of growing degree days (GDD) from June 1 to the first planting at Pendleton was lower for the first 2 years $(1,883$ and 1,886 GDD) than the last 2 years (1,918 and 2,150 GDD) of study. Mean soil temperature at the $10-\mathrm{cm}$ depth on the day of planting (Table 1) and mean soil temperature over the 21 days following planting (data not presented) increased during successive years for the experiment. Accumulation of GDD between September 1 and the first planting were highest during crop year 1999, lowest during crop year 1997, and intermediate during crop years 1996 and 1998; 191, 48, 159 , and 101 GDD, respectively. Soil temperature at the $10-\mathrm{cm}$ depth was generally favorable for rapid seed germination and seedling emergence for planting dates during September and declined to suboptimal temperatures $\left(<16^{\circ} \mathrm{C}\right)$ during mid- to late October each year (Table 1).

Diseases and grain yield. During 3 of 4 years, grain yields in experiment 1 (Exp. 1) were lower for plantings in September than for later planting dates (Table 1). The same pattern occurred at Pendleton but not Moro in experiment 2 (Exp. 2; Table 2). When data for Exp. 1 were grouped over 4 years, there was a significant effect of planting interval on grain yield (Table 3). Yield was higher for October than September plantings and was intermediate for plantings during late November or early December.
Cephalosporium stripe, crown rot, eyespot, and take-all were more prevalent during the earliest plantings and generally became reduced or absent in plantings made during mid- to late October and later (Tables 1 and 2). When grouped over 4 years, there was a significant effect of planting interval on incidence of Fusarium crown rot and eyespot but not Rhizoctonia root rot or take-all (Table 3).

During 1996 in Exp. 1 and Exp. 2 at Pendleton, crown rot, eyespot, Rhizoctonia root rot, and take-all were present at comparable levels of incidence for most planting dates. The same drill was used for September plantings in each experiment but different drills and row openers were used for the October plantings. The type of drill and opener had no apparent influence on incidence of crown rot, eyespot, and take-all in these experiments. The incidence of Rhizoctonia root rot appears to have been greater at each planting date in Exp. 2 compared with Exp. 1 but possible differences could not be evaluated with statistics.

Grain yield and disease incidence or severity were not significantly $(P<0.05)$ correlated at Moro in Exp. 2 but many significant associations between yield and disease were identified in both experiments at Pendleton. In Exp. 1, eyespot incidence at Pendleton was significantly negatively associated with grain yield during $1996(P$ $\left.=0.01, R^{2}=0.97, n=4\right)$, during $1998(P=$ $\left.0.02, R^{2}=0.88, n=5\right)$, and when data were grouped across years (Table 4). Yields were negatively correlated with Cephalosporium stripe incidence during $1997\left(P=0.06, R^{2}=0.87, n=5\right)$. Yields were also negatively associated with crown

Table 4. Correlation significance $(P)$ and coefficient $(r)$ for associations between four diseases and the ordinal date for planting, seven moisture characteristics, 12 temperature characteristics, and grain yield in an experiment with Stephens winter wheat conducted over 4 years (1996 to 1999) at Pendleton, OR ( $n$ $=19$ for each statistic)

\begin{tabular}{|c|c|c|c|c|c|c|c|c|}
\hline \multirow[b]{2}{*}{ Parameter } & \multicolumn{2}{|c|}{ Fusarium crown rot } & \multicolumn{2}{|c|}{ Eyespot } & \multicolumn{2}{|c|}{ Take-all } & \multicolumn{2}{|c|}{ Rhizoctonia root rot } \\
\hline & $\boldsymbol{P}$ & $\boldsymbol{r}$ & $\boldsymbol{P}$ & $r$ & $\boldsymbol{P}$ & $r$ & $\boldsymbol{P}$ & $r$ \\
\hline Ordinal day of year for planting (1-365) & $<0.01$ & -0.79 & $<0.01$ & -0.68 & 0.58 & -0.14 & 0.43 & -0.19 \\
\hline Soil water in seed zone at planting (\% wt/wt) & 0.28 & -0.26 & 0.22 & -0.30 & 0.15 & -0.34 & 0.93 & 0.02 \\
\hline \multicolumn{9}{|l|}{ Precipitation $(\mathrm{mm})$} \\
\hline For entire crop year (1 Sep to $30 \mathrm{Aug}$ ) & 0.59 & -0.13 & 0.91 & 0.03 & 0.29 & -0.26 & 0.38 & -0.22 \\
\hline From planting date until $31 \mathrm{Dec}$ & 0.12 & 0.37 & 0.12 & 0.37 & 0.28 & 0.26 & 0.81 & 0.06 \\
\hline From 1 June to planting date & 0.02 & -0.54 & 0.04 & -0.47 & 0.36 & -0.22 & 0.77 & -0.07 \\
\hline From 1 Sep to planting date & $<0.01$ & -0.58 & 0.02 & -0.53 & 0.66 & -0.11 & 0.30 & -0.25 \\
\hline For 21 days before planting & 0.06 & -0.44 & 0.12 & -0.37 & 0.93 & -0.02 & 0.50 & -0.17 \\
\hline For 21 days after planting & 0.05 & -0.46 & 0.03 & -0.50 & 0.95 & -0.02 & 0.61 & -0.12 \\
\hline \multicolumn{9}{|l|}{ Temperature $\left({ }^{\circ} \mathrm{C}\right)$ in air or soil } \\
\hline Maximum on planting date (air) & $<0.01$ & 0.68 & 0.09 & 0.40 & 0.72 & 0.09 & 0.78 & 0.07 \\
\hline Minimum on planting date (air) & $<0.01$ & 0.64 & 0.05 & 0.46 & 0.87 & 0.04 & 0.46 & -0.18 \\
\hline Maximum on planting date (10-cm depth) & $<0.01$ & 0.78 & 0.04 & 0.49 & 0.07 & 0.43 & 0.57 & 0.14 \\
\hline Minimum on planting date (10-cm depth) & $<0.01$ & 0.78 & 0.03 & 0.50 & 0.05 & 0.46 & 0.70 & 0.10 \\
\hline Average daily on planting date (10-cm depth) & $<0.01$ & 0.73 & 0.03 & 0.50 & 0.06 & 0.44 & 0.62 & 0.12 \\
\hline Average daily for 21 days after planting (10-cm depth) & $<0.01$ & 0.83 & $<0.01$ & 0.63 & 0.03 & 0.50 & 0.61 & 0.13 \\
\hline \multicolumn{9}{|l|}{ Growing-degree days (GDD) } \\
\hline For entire crop year (1 Sep to $30 \mathrm{Aug}$ ) & 0.54 & 0.15 & 0.82 & -0.06 & 0.04 & 0.48 & 0.38 & 0.22 \\
\hline From planting date until $31 \mathrm{Dec}$ & $<0.01$ & 0.85 & $<0.01$ & 0.70 & 0.38 & 0.20 & 0.56 & 0.14 \\
\hline From 1 June to planting date & $<0.01$ & -0.75 & $<0.01$ & -0.70 & 0.40 & 0.20 & 0.82 & -0.06 \\
\hline From 1 Sep to planting date & $<0.01$ & -0.81 & $<0.01$ & -0.70 & 0.95 & -0.02 & 0.91 & -0.03 \\
\hline For 21 days before planting & $<0.01$ & 0.83 & $<0.01$ & 0.63 & 0.34 & 0.23 & 0.48 & 0.17 \\
\hline For 21 days after planting & $<0.01$ & 0.88 & $<0.01$ & 0.75 & 0.43 & 0.19 & 0.66 & 0.11 \\
\hline Grain yield & 0.03 & -0.49 & $<0.01$ & -0.62 & 0.91 & 0.03 & 0.99 & -0.01 \\
\hline
\end{tabular}


rot incidence in $1998\left(P<0.01, R^{2}=0.97\right.$, $n=5)$ and when data were grouped across years (Table 4). Take-all incidence and severity were variable from season to season, and differences over years were significant when data were grouped by planting date interval and analyzed by ANOVA with years as block $(P<0.01, n=4)$. Takeall incidence was least $(P<0.05)$ during 1996 and 1997, intermediate during 1998, and greatest during 1999, with means across planting dates for those years being $9,5,23$, and $90 \%$ plants, respectively $\left(\mathrm{LSD}_{0.05}=12\right)$. Take-all incidence was negatively associated with grain yield only during $1998\left(P=0.06, R^{2}=0.76, n=5\right)$. Rhizoctonia root rot incidence and severity were variable over years and were never correlated with grain yield.

Sufficient data were available for multiple regression analysis using a stepwise subset addition model in five of the six location-year tests; all except Moro in Exp. 2. Yield at Pendleton in Exp. 2 was most strongly associated with a combined function of crown rot plus eyespot $\left(R^{2}=\right.$ 0.98). Yield in Exp. 1 was most strongly associated individually with eyespot $\left(R^{2}=\right.$ $0.97)$ in 1996 and crown $\operatorname{rot}\left(R^{2}=0.97\right)$ in 1998 and with combined functions, including crown rot and Cephalosporium stripe $\left(R^{2}=0.99\right)$ in 1997 and crown rot, take-all, and Rhizoctonia root rot $\left(R^{2}=0.97\right)$ in 1999. Therefore, each of these diseases was implicated as an important determinant of yield suppression at Pendleton. Crown rot was identified as an important contributor to yield variability in four of five tests. When data in Exp. 1 were evaluated by regression analysis over all 4 years, grain yield was negatively associated more strongly with eyespot $\left(R^{2}=\right.$ $0.38)$ than crown rot $\left(R^{2}=0.24\right)$ and was not significantly associated with Rhizoctonia root rot or take-all. Multiple regression analyses that considered effects of two or more diseases did not reveal any stronger associations than with eyespot alone.

Diseases and climatic parameters. Associations between climatic parameters and crown rot, eyespot, and take-all but not Rhizoctonia root rot occurred in both experiments. Occurrence of Cephalosporium stripe was too infrequent to examine these associations, and data were also inadequate for evaluating these associations in plantings at Moro in Exp. 2.

Crown rot at Pendleton in Exp. 1 was correlated more with measures of temperature than moisture (Table 4). This disease was directly correlated with GDD accumulated over 21 days before and after planting in Exp. 1 (Table 4) and Exp. 2 (before: $P=0.07, R^{2}=0.64, n=4$; after: $P=0.08$, $\left.R^{2}=0.83, n=4\right)$. Crown rot was also directly correlated with GDD from planting to December 31 (Table 4). Additionally, crown rot was directly correlated with maximum, minimum, and mean daily temperatures at the $10-\mathrm{cm}$ depth on the plant- ing dates in Exp. 1 and with mean temperature at the $10-\mathrm{cm}$ depth for 21 days following planting in Exp. 1 and Exp. $2(P$ $\left.=0.08, R^{2}=0.85, n=4\right)$.

The year (1997) with lowest crown rot incidence for the two earliest planting dates was characterized by the longest duration of a dry soil surface between these planting dates and the first soilwetting rainfall. In each case, the first rainfall occurred nearly a month after seed was planted into moist soil below the dust mulch. Disease incidence for the midOctober plantings became greater during the driest year compared with the wetter years. Crown rot was negatively correlated with cumulative precipitation from September 1 to planting in Exp. 1 and Exp. 2 $\left(P=0.02, R^{2}=0.96, n=4\right)$ and from June 1 to planting in Exp. 1 and Exp. $2(P=$ 0.02, $\left.R^{2}=0.96, n=4\right)$. Crown rot in Exp. 1 was also negatively correlated with cumulative precipitation for 21 days before and after planting. Crown rot was not significantly associated with soil water content at the time of planting, total precipitation during the crop year, or precipitation between planting and December 31 .

When parameters were analyzed by stepwise backward multiple regression analysis, incidence of crown rot was most highly correlated with increasingly greater accumulation of GDD for 21 days following planting (percent crown rot $=-23.46+$ 0.23 GDD; $R^{2}=0.77$ ). The next most important parameter, a positive influence from precipitation during the 21 days after planting, added little strength to the regression $\left(R^{2}=0.80\right)$. The stronger crown rot association with cumulative GDD than rainfall supports the stronger individual correlations for measures of thermal than moisture parameters (Table 4).

Eyespot incidence in both experiments at Pendleton was directly correlated with cumulative GDD from planting to December 31 and for 21 days before and after planting, as exemplified in Exp. 1 (Table 4). The disease was also directly correlated with the mean temperature at the $10-\mathrm{cm}$ depth for 21 days following planting and negatively correlated with precipitation over the 21 days after planting in Exp. 1 (Table 4) but not Exp. 2. None of the regressions of eyespot incidence against multiple environmental parameters were higher than for cumulative GDD for 21 days following planting (percent eyespot $=$ $-8.05+0.10$ GDD; $R^{2}=0.57$ ).

In Exp. 1, take-all incidence was negatively associated with cumulative GDD from September 1 to planting during 1999 $\left(P=0.03, R^{2}=0.84, n=5\right)$ and for 21 days before planting during $1996(P=$ $\left.0.07, R^{2}=0.86, n=4\right)$ and $1999(P<0.01$, $\left.R^{2}=0.92, n=5\right)$. Take-all incidence was positively associated with GDD accumulation and mean temperature at the $10-\mathrm{cm}$ depth during the 21-day interval after planting during 1996, 1998, and 1999 (range of statistical values was $P=0.01$ to $0.07, R^{2}=0.72$ to $0.90, n=4$ to 5 ) and was negatively associated (range was $P=0.06$ to $0.07, R^{2}=0.72$ to $0.74, n=5$ ) with these parameters during 1997. Take-all incidence was positively associated with rainfall between planting and December 31 during $1996\left(P=0.02, R^{2}=0.96, n=4\right)$ and 1998 $\left(P=0.08, R^{2}=0.71, n=5\right)$. When grouped over years, soil temperature at the time of planting and GDD for the crop year were significantly associated with incidence of take-all (Table 4). None of the regressions between take-all incidence and multiple environmental parameters in Exp. 1 were higher than for combined negative influence of soil moisture in the seed zone at planting time and positive influences of GDD from June 1 to planting and from planting to December 1 (percent take-all = $-726.83-0.70$ soil moisture + 0.26 GDD since 1 June +0.69 GDD from planting to 1 December; $R^{2}=0.96$ ). In Exp. 2, take-all was positively correlated with mean soil temperature at the $10-\mathrm{cm}$ depth for 21 days following planting $\left(P<0.01, R^{2}=0.98, n\right.$ $=4)$, cumulative GDD for 21 days following planting $\left(P<0.01, R^{2}=0.98, n=4\right)$, and GDD from planting to December 31 $\left(P=0.03, R^{2}=0.94, n=4\right)$.

\section{DISCUSSION}

Cephalosporium stripe, crown rot, eyespot, and take-all were most prevalent and severe in early-planted winter wheat. Each of these diseases develops slowly in dry environments because the pathogens typically infect seedlings but do not cause significant damage until plants approach maturation. They each have the potential to restrict water uptake and translocation in individual tillers or entire plants late in the growing season, amplifying the deleterious effect of late-season water stress on grain filling and causing premature ripening characterized by shriveled kernels (40).

Crown rot was identified most frequently as an important contributor to yield suppression in this study. Disease incidence and severity were consistently greater when winter wheat was planted during early September than after the first or second week of October, as reported previously $(11,24,30)$, and attributed to greater plant water stress near the end of the growing season $(6,11,13)$. This relationship is of particular importance in the semiarid climate of the inland PNW where precipitation occurs mostly or entirely during late autumn through early spring, and where water stored deeply in the soil profile during the preceding summer fallow is often the only water available for winter wheat after heads emerge (37).

Infection of wheat plants by F. pseudograminearum is strongly influenced by both moisture and temperature. Infection of crowns and subcrown internodes occurs optimally in moist soil having a narrow range of water potentials from -0.3 to -0.6 
$\mathrm{MPa}$, with very little infection occurring in soils drier than $-1.5 \mathrm{MPa}(21,22)$. In-crop rainfall sufficient to wet soil to less than $-1.5 \mathrm{MPa}$ appears to be required for infection of plants (42). The pathogen can grow at a much broader range of water potentials $(14,44)$ but microbial antagonism restricts the capacity of the pathogen to infect the host when soils are wetter than $-0.3 \mathrm{MPa}$ or dryer than $-0.6 \mathrm{MPa}(6,22)$. In both experiments, crown rot was not associated with soil water content in the moist seed zone covered by dust mulch. There also was no discernable influence on crown rot when the seed zone was too dry $(<-0.2 \mathrm{MPa})$ for rapid seed germination and seedling emergence in several earlyseason plantings during 1997 and 1999, which were years with little preplant precipitation. The lowest crown rot incidence for the two earliest planting dates occurred in the year (1997) characterized by the longest duration of a dry soil surface, when the first significant rainfall occurred nearly a month after the second planting date. Crown rot in both experiments also became significantly less severe with increasing amounts of cumulative precipitation during the interval from September 1 through the planting date, and for 21 days following the planting date, indicating that a dry soil surface before planting and soon after emergence was a factor favoring infection of seedlings emerging from seed planted into moist soil below the dust mulch. As shown by Swan et al. (42), who determined that in-season rainfall was required for infection, the greatest disease incidence in this study occurred when rain wetted the surface dust mulch after seedlings emerged. Primary infections of subcrown internode and crown tissues apparently occurred when pathogen-infested residue was wetted after seedlings were well established.

Although most emphasis in the PNW has been placed on moisture parameters associated with crown rot, the disease incidence and severity in this study were consistently correlated more highly with measures of thermal than moisture parameters. Rapid plant development early in the season has an important influence on the rate at which water is extracted and depleted from a given amount of water stored in the soil profile in this semiarid, winter-dominant rainfall environment. Moreover, high soil temperature favors infection of wheat by $F$. pseudograminearum $(7,44,47)$. In both experiments of this study, over the 21-day interval after planting, crown rot was highly and positively correlated with the mean temperature at the $10-\mathrm{cm}$ depth and accumulation of GDD. These relationships indicate that crown rot became most severe when soils were dry and warm after seed was planted, as has been reported for controlledenvironment studies (7). It is also reported that $F$. pseudograminearum does not infect seedlings at temperatures less than $12^{\circ} \mathrm{C}$ (18), a temperature limit achieved during mid- to late October and coinciding with the planting dates associated with a decrease in the incidence of crown rot detected during the following spring. Results of this study and previous research appear to satisfy requirements for developing a crown rot module in growth-simulation models. The parameter of greatest importance in this study was GDD accumulated for 21 days after planting. Rainfall over that same time period was also important but contributed less than GDD to the strength of correlations with crown rot in this study.

The date of planting susceptible winter wheat cultivars has a greater influence on eyespot incidence than any management strategy other than fungicide application $(10,17)$. Eyespot becomes most damaging when wheat is planted during late summer to early autumn $(4,20)$. Initial infection occurs when spores borne on crop debris are splashed onto stems of young plants. Frequent rain and high humidity are necessary for sporulation and infection but consistent associations between precipitation and eyespot incidence were not detected in this study. Following infection, disease establishment becomes a function of accumulated temperature. Eyespot incidence in both experiments of this study was strongly associated with cumulative GDD over the 21-day interval following planting and from planting to December 31. These findings are in agreement with reports that eyespot occurs at a higher frequency when winter wheat tillers extensively and develops a robust plant canopy before growth slows during winter $(4,10,20)$. Although these results support developing an eyespot module for a growth-simulation model, the primary management strategy for controlling eyespot is likely to continue to focus upon deployment of resistance genes (40).

The incidence and severity of take-all were greatest during the earliest planting dates in two experiments during one crop year (1996), with similar but not statistically significant trends in 1998 and 1999. Werker and Gilligan (46) and Folwell et al. (19) also reported that effects of planting were variable over seasons and locations, with planting dates having little effect on disease incidence during a year with a very dry autumn and a strong effect during a year with a very wet autumn (46). Colbach et al. (9) determined that delayed planting reduced severity of take-all in the primary infection cycle during early stages of the epidemic but the effect of sowing date on take-all severity for the secondary cycle during early spring was variable, leading to variable effects of planting date on disease severity in mature plants. Nevertheless, Colbach et al. (9) concluded that planting date was the agronomic practice exhibiting the most important individual effect on disease development.
An acute form of take-all is favored by cool, wet soil (12) but a chronic form is commonly reported in very dry environments $(34,35,39)$. Roget (33) determined that growing-season rainfall was the principal environmental factor influencing take-all in autumn-planted wheat in South Australia. In this study, take-all was most pronounced during a comparatively dry year (1999) characterized by a warm seedzone temperature, and was more strongly and positively associated with GDD and soil temperature than with rainfall after planting. Optimal growth of the pathogen occurs at water potentials of -0.8 to -1.2 $\mathrm{MPa}$ at temperatures from 20 to $30^{\circ} \mathrm{C}$ (14), but Cotterill and Sivasithamparam (15) reported that pathogen inoculum density remained high when soil was not moistened periodically and was reduced dramatically by microbial antagonism when warm soil was wetted periodically, as may occur during summer prior to planting. Take-all incidence and severity in this study were negatively associated with GDD over the 21 days prior to planting during the two warmest years (1996 and 1999) which also had greatest precipitation prior to the first planting date. However, there was no association between take-all and GDD prior to planting during a year (1998) in which rainfall was sparse. Takeall was minimal at all planting dates during the coldest and driest year (1997) of this study, as previously reported by Augustin (2). As shown elsewhere $(33,38)$, it appears that take-all is well suited for modeling in the PNW. Parameters of greatest importance in this study were soil moisture in the seed zone at planting time and accumulation of GDD during the summer and autumn.

Data in this study were inadequate to evaluate associations between Cephalosporium stripe incidence and soil moisture and temperature parameters. However, infection and disease incidence are known to be more prevalent when seed is planted into wet soil $(1,5)$ at temperatures greater than $13^{\circ} \mathrm{C}$ during the 14-day interval following planting (29). Greater disease severity is associated with the length of time when the average air temperature is between 0 and $15^{\circ} \mathrm{C}$ from 1 January until plant maturation, and with the amount of rainfall when temperatures are within that range (5). Because measurements of air temperature and soil temperature provide equal levels of precision for predicting winter wheat phenology (26), the moisture and temperature relationships reported previously appear amenable for adaptation as a module in a winter wheat growthsimulation model.

Rhizoctonia root rot was not individually associated with yield reduction in this study and is unlikely to become amenable to development of a predictive model. Disease ratings were nearly uniform over six planting dates even though the percent- 
age of affected plants was greater for planting dates from early September to early October than for planting dates from mid-October to mid-November. Factors that may complicate the modeling of this disease include the variability of optimal temperature for growth and pathogenicity of isolates of $R$. solani AG-8 (25) and the complex of Rhizoctonia spp. (40) present in PNW soils.

A single grain drill with hoe-type openers was used to plant winter wheat over sequential planting dates in Exp. 2. The effect of planting dates on development of crown rot, eyespot, Rhizoctonia root rot, and take-all in Exp. 2 was similar to that in Exp. 1, where drills with three different types of openers were used over sequential planting dates. Factors such as seed depth and soil environment appeared to have influenced development of diseases more than differences in soil disturbance created by different styles of seed drills during the late-season plantings. This observation was of particular importance for crown rot. Wildermuth et al. (48) found a direct correlation between crown rot incidence and depth of crown formation, which is controlled by both plant genetics and depth of seeding (45). This experiment indicated that differing levels of disturbance for inoculum-infested soil and plant residues in and above the seed zone at the time of planting did not influence crown rot development.

Diseases caused by pathogens which infect roots and crowns were strongly associated with reduced yield often observed for early-planted winter wheat in very dry environments. In the absence of these root and crown diseases, temperature and moisture are the major determinates of winter wheat response to seeding date (28). Early planting is considered especially detrimental in arid regions because water stored deeply in the soil profile becomes depleted for later development, when peak wateruse rates occur during the period from heading to completed head extension (31). Therefore, timely planting is considered essential for a well-timed phenological development. Results of experiments reported in this article indicate that diseases must be considered as important as climatic conditions in limiting the yield of winter wheat seed planted early into warm, moist soil.

\section{ACKNOWLEDGMENTS}

I thank the Oregon Wheat Commission and USDA-CSREES-Pacific Northwest STEEP II Research Program for funding; L.-M. Patterson, K. Rhinhart, and S. Easley for technical assistance; and M. Stoltz, C. Chen, and W. Payne for contributions of labor and guidance.

\section{LITERATURE CITED}

1. Anderegg, J. C., and Murray, T. D. 1988. Influence of soil matric potential and soil $\mathrm{pH}$ on Cephalosporium stripe of winter wheat in the greenhouse. Plant Dis. 72:1011-1016.

2. Augustin, C., Jacob, H. J., and Werner, A.
1997. Effects on growth of wheat plants of isolates of Gaeumannomyces/Phialophoracomplex fungi in different conditions of soil moisture, temperature, and photoperiod. Eur. J. Plant Pathol. 103:417-426.

3. Bockus, W. W., Bowden, R. L., Hunger, R. M., Morrill, W. L., Murray, T. D., and Smiley, R. W., eds. Compendium of Wheat Diseases and Insects, 3rd ed. American Phytopathological Society Press, St. Paul, MN.

4. Bruehl, G. W. 1968. Ecology of Cephalosporium stripe disease of winter wheat in Washington. Plant Dis. Rep. 52:590-594.

5. Bruehl, G. W., Nelson, W. L., Koehler, F., and Vogel, O. E. 1968. Experiments with Cercosporella foot rot (strawbreaker) disease of winter wheat. Wash. Agric. Exp. Stn. Bull. 694. Washington State University, Pullman.

6. Burgess, L. W., Backhouse, D., Summerell, B. A., and Swan, L. J. 2001. Crown rot of wheat. Pages 271-294. in: Fusarium. B. A. Summerell, J. F. Leslie, D. Backhouse, W. L. Bryden, and L. W. Burgess, eds. American Phytopathological Society Press, St. Paul, MN.

7. Calhoun, J., and Park, D. 1964. Fusarium diseases of cereals. I. Infection of wheat plants, with particular reference to the effects of soil moisture and temperature on seedling infection. Trans. Br. Mycol. Soc. 47:559-572.

8. Chen, C., Payne, W. A., Smiley, R. W., and Stoltz, M. A. 2003. Yield and water-use efficiency of eight wheat cultivars planted on seven dates in northeastern Oregon. Agron. J. 95:836-843.

9. Colbach, N., Lucas, P., and Meynard, J.-M. 1997. Influence of crop management on takeall development and disease cycles on winter wheat. Phytopathology 87:26-32.

10. Colbach, N., and Saur, L. 1998. Influence of crop management on eyespot development and infection cycles of winter wheat. Eur. J. Plant Pathol. 104:37-48.

11. Cook, R. J. 1981. Fusarium diseases of wheat and other small grains in North America. Pages 39-52 in: Fusarium: Diseases, Biology and Taxonomy. P. E. Nelson, T. A. Toussoun, and R. J. Cook, eds. The Pennsylvania State University Press, University Park.

12. Cook, R. J. 1981. The effect of soil reaction and physical conditions. Pages 343-352 in: Biology and Control of Take-all. M. J. C. Asher and P. J. Shipton, eds. Academic Press, London.

13. Cook, R. J. 1981. Water relations in the biology of Fusarium. Pages 236-244 in: Fusarium: Diseases, Biology and Taxonomy. P. E. Nelson, T. A. Toussoun, and R. J. Cook, eds. The Pennsylvania State University Press, University Park.

14. Cook, R. J., and Christen, A. A. 1976. Growth of cereal root-rot fungi as affected by temperature-water potential interactions. Phytopathology 66:193-197.

15. Cotterill, P. J., and Sivasithamparam, K. 1987. Intermittent wetting of soils at high temperature reduces survival of the take-all fungus. Plant Soil 103:289-291.

16. Dahlke, B. J., Oplinger, E. S., Gaska, J. M., and Martinka, M. J. 1993. Influence of planting date and seeding rate on winter wheat grain yield and yield components. J. Prod. Agric. 6:408-414

17. Dickens, L. E. 1964. Eyespot footrot of winter wheat caused by Cercosporella herpotrichoides. Cornell Univ. Agric. Exp. Stn. Memoir 390. Ithaca, NY.

18. Dickson, J. G., 1923. Influence of soil temperature and moisture on the development of seedling blight of cereals. Proc. Nat. Acad. Sci. Wash. 9:434-439.

19. Folwell, R. J., Cook, R. J., Heim, M. N., and Moore, D. L. 1991. Economic significance of take-all on winter wheat in the Pacific Northwest USA. Crop Prot. 10:391-395.

20. Herrman, T., and Wiese, M. V. 1985. Influence of cultural practices on incidence of foot rot in winter wheat. Plant Dis. 69:948-950.

21. Liddell, C. M., and Burgess, L. W. 1985. Wax layers for partitioning soil moisture zones to study the infection of wheat seedlings by Fusarium graminearum. Pages 206-208 in: Ecology and Management of Soilborne Plant Pathogens. C. A. Parker, A. D. Rovira, K. J. Moore, P. T. W. Wong, and J. F. Kollmorgan, eds. American Phytopathological Society, St. Paul, MN.

22. Liddell, C. M., and Burgess, L. W. 1988. Wax partitioned soil columns to study the influence of soil moisture potential on the infection of wheat by Fusarium graminearum Group 1 . Phytopathology 78:185-189.

23. Line, R. F., and Cu, R. M. 1999. MoreCrop: Managerial option for reasonable economic control of rusts and other pathogens. An expert system for managing diseases of wheat in the PNW. http://pnw-ag.wsu.edu/MoreCrop/index. htm. (last accessed 7 September 2008).

24. Maric, A. 1981. Fusarium diseases of wheat and corn in Eastern Europe and the Soviet Union. Pages 77-93 in: Fusarium: Diseases, Biology, and Taxonomy. P. E. Nelson, T. A. Toussoun, and R. J. Cook, eds. The Pennsylvania State University Press, University Park.

25. Mazzola, M., Smiley, R. W., Rovira, A. D., and Cook, R. J. 1996. Characterization of Rhizoctonia isolates, disease occurrence and management in cereals. Pages 259-267 in: Rhizoctonia Species: Taxonomy, Molecular Biology, Ecology, Pathology and Disease Control. B. Sneh, S. Jabaji-Hare, S. Neate and G. Dijst. eds. Kluwer Academic Publishers, Dordrecht, The Netherlands.

26. McMaster, G. S., and Wilhelm, W. W. 1998. Is soil temperature better than air temperature for predicting winter wheat phenology? Agron. J. 90:602-607.

27. Ogg, A. G., Jr., Smiley, R. W., Pike, K. S., McCaffrey, J. P., Thill, D. C., and Quisenberry, S. S. 1999. Integrated pest management for conservation systems. Pages 97-128 in: Advances in Conservation Farming. E. L. Michalson, R. I. Papendick, and J. E. Carlson, eds CRC Press, Boca Raton, FL.

28. Paulsen, G. M. 1987. Wheat stand establishment. Pages 384-389 in: Wheat and Wheat Improvement, 2nd ed. E. G. Heyne, ed. American Society of Agronomy, Madison, WI.

29. Pool, R. A. F., and Sharp, E. L. 1969. Some environmental and cultural factors affecting Cephalosporium stripe of winter wheat. Plant Dis. Rep. 53:898-902.

30. Purss, G. S. 1971. Effect of planting time on the incidence of crown rot (Gibberella zeae) in wheat. Aust. J. Exp. Agric. Anim. Husb. 11:8589.

31. Rickman, R. W., Allmaras, R. R., and Ramig, R. E. 1978. Root-sink descriptions of water supply to dryland wheat. Agron. J. 70:723-728.

32. Rickman, R. W., Waldman, S. E., and Klepper, B. 1996. MODWht3: A development-driven wheat growth simulation. Agron. J. 88:176185.

33. Roget, D. K. 2001. Prediction modelling of soilborne plant diseases. Australas. Plant Pathol. 30:85-89.

34. Russell, R. C. 1931. Study of take-all (Ophiobolus graminis) of wheat. Rep. Dep. Agric. Can. 1930:78-82.

35. Russell, R. C. 1934. Studies in cereal diseases. X. Studies of take-all and its causal organism, Ophiobolus graminis Sacc. Can. Dep. Agric. Bull. 170. Nova Scotia.

36. Schillinger, W. F., Kennedy, A. C., and Young, D. L. 2007. Eight years of annual no-till cropping in Washington's winter wheat-summer fallow region. Agric. Ecosyst. Environ. 120:345-358.

37. Schillinger, W. R., Papendick, R. I., Guy, S. O., Rasmussen, P. E., and Kessel, C. van. 2006. 
Dryland cropping systems in the western United States. Pages 365-393 in: Dryland Agriculture, 2nd ed. G. A. Peterson, P. W. Unger, and W. A. Payne, eds. Agron. Monogr. 23. American Society of Agronomy, Madison, WI.

38. Schoeny, A., and Lucas, P. 1999. Modeling of take-all epidemics to evaluate the efficacy of a new seed-treatment fungicide on wheat. Phytopathology 89:954-961.

39. Sivasithamparam, K., and Parker, C. A. 1981. Physiology and nutrition in culture. Pages 125 150 in: Biology and Control of Take-all. M. J. C. Asher and P. J. Shipton, eds. Academic Press, London.

40. Smiley, R. W., Backhouse, D., Lucas, P., and Paulitz, T. Diseases which challenge global wheat production - root, crown, and culm rots.
In: Wheat: Science and Trade. B. F. Carver, ed. Blackwell Publishing, Ames, IA. In press.

41. Smiley, R. W., and Uddin, W. 1993. Influence of soil temperature on Rhizoctonia root rot $(R$. solani AG-8 and $R$. oryzae) of winter wheat. Phytopathology 83:777-785.

42. Swan, L. J., Backhouse, D., and Burgess, L. W. 2000. Surface soil moisture and stubble management practice effects on the progress of infection of wheat by Fusarium pseudograminearum. Aust. J. Exp. Agric. 40:693-698.

43. Waldman, S. E., and Rickman, R. W. 1996. MODCROP: A crop simulation framework. Agron. J. 88:170-175.

44. Wearing, A. H., and Burgess, L. W. 1979. Water potential and the saprophytic growth of Fusarium roseum "Graminearum". Soil Biol.
Biochem. 11:661-667.

45. Webb, R. B., and Stephens, D. E. 1936. Crown and root development in wheat varieties. J. Agric. Res. 52:569-583.

46. Werker, A. R., and Gilligan, C. A. 1990. Analysis of the effects of selected agronomic factors on the dynamics of the take-all disease of wheat in field plots. Plant Pathol. 39:161 177.

47. Wildermuth, G. B., and McNamara, R. B 1994. Testing wheat seedlings for resistance to crown rot caused by Fusarium graminearum group 1. Plant Dis. 78:949-953.

48. Wildermuth, G. B., McNamara, R. B., and Quick, J. S. 2001. Crown depth and susceptibility to crown rot in wheat. Euphytica 122:397-405. 